\title{
TOWARDS PLAY-BASED LEARNING PRACTICE
}

\author{
Dewi Mulia \\ Deakin University, Melbourne Australia \\ dmulia@deakin.edu.au
}

\begin{abstract}
This paper provides the rationale for an overview and a discussion of the issues that affect best practices for play-based learning, particularly the implications of adults' attitudes regarding child's play and learning for play-based learning practice in early childhood educational settings in Indonesia. The concept of play-based learning can be attributed to the National Early Years Learning Framework in Indonesia. However, the practice remains challenging as the result of diverse concepts of child's play and learning. This discussion begins with an overview of the framework and of government support. It details the relevant research on the challenges that educators and teachers have faced with the implementation of the framework.
\end{abstract}

Keywords: play-based learning, early years learning

\begin{abstract}
Abstrak
Artikel ini memberikan rasional terhadap pandangan dan diskusi terhadap hal-hal yang berhubungan dengan pembelajaran berbasis permainan, khususnya melihat implikasinya terhadap perilaku orang dewawa terhadap permainan anak dan pembelajaran untuk praktek pembelajaran anak berbasis permainan pada tahap pendidikan usia dini di Indonesia. Konsep pembelajaran berbasis permainan dikaitkan dengan Kerangka Pembelajaran Usia di Indonesia. Bagaimanapun juga, pelaksanaan pembelajaran merupakan sebuah tantangan sebagai akibat dari banyaknya konsep yang berbeda tentang permainan dan pembelajaran anak. Diskusi dalam artikel ini dimulai dengan pembahasan tentang kerangka dan dukungan pemerintah terhadap pembelajaran dengan permainan. Berikutnya memberikan gambaran beberapa penelitian dan tantangan yang dihadapi oleh para pendidik dan para guru dalam implementasi dari kerangka pembelajaran berbasis permainan.
\end{abstract}

Kata kunci: pemebeljaran berbasis permainan, pembelajaran usia dini

\section{Overview of the National Early Years Learning Framework of In- donesia}

The Indonesian government is committed to supporting children's positive learning and development and providing children with a strong platform for future success. The National Early Years Learning Framework offers educators, teachers, and policy-makers who work with children a set of principles and a practice guide. The framework advocates play-based learning as an approach in the early learning programme. Known as Taman Kanak-kanak (TK), it arranges the programme into two grades (grade $\mathrm{A}$ for children aged six years and grade B for children aged five years), playgroups (for children aged two to four years - Kelompok Bermain) and day care centres (from birth to the age of five yearsTaman Penitipan Anak). 
2. What does the play-based learning curriculum look like in the National Early Years Learning Framework?

The framework establishes six principles of early childhood pedagogy (Departemen Pendidikan Nasional, 2009, p. 37) which focus on scaffolding children to enable them to achieve learning and development outcomes. The six principles follow:

1. Responsiveness: Play activity should be based on children's development, needs, interests, and personality/behaviour/characteristics;

2. A holistic approach: This involves paying attention to children's well-being, including good physical health, nutrition, education, protection, and services;

3. A learning-through-play approach;

4. A gradual process: This involves regarding learning as a lifelong process and intellectual habit;

5. An active, creative, interactive, effective, and fun learning approach; and

6. A child-focused learning approach.

The framework emphasises playbased learning as one of the key contexts of high-quality early learning and care programmes. According to the framework (Ministry of Education, 2009), play-based learning is a context of play which is safe, comfortable, clean, and attractive. A variety of play materials should meet the guidelines and standards required for healthy and safe alignment with lesson plan goals. Moreover, play involves nature and the environment.

As indicated above, another principle that is commonly adopted in early childhood educational settings in Indonesia is the holistic approach. This approach ensures that children develop gross motor, character-related, social, spiritual, and emotional skills (Morrissey \& Warner, 2007). In the Indonesian context, a holistic approach includes aspects of religious worship. From the above details, it is clear that teachers, educators, and school management staff should pro- vide a play-based context for learning and an essential strategy that underpins the six principles of the early learning framework.

\section{How does the framework define play?}

The National Early Years Learning Framework defines play as a fun indoor and outdoor activity or physically active play (Steglin, 2005). Physically active play allows children to learn about and understand nature and the environment. The framework recognises the importance of using nature and the environment to provide resources, materials, and experiences (including creativity and physical, cognitive, and emotional strength) which enhance child development.

The framework indicates that, to organise play activity, parents should also be involved in play. This implies that the framework defines play as guided play (2009, p. 38 ). In this respect, the government recognises the importance of adults' role in child's play. However, the framework gives a limited description of parental involvement in child's play in the school context.

The Indonesian government provides local early learning institutions with the opportunity to develop play-based learning practice which meets their local needs and interests. According to Moss (2007), giving schools the opportunity to value local contexts and take individuals into account is positive. However, a clear outline of the concept of play is vital. As Bertrand (2007) emphasizes, the government plays a major role in establishing the concept of play and strategies for delivering the concept and in monitoring play-based programmes. Precision regarding shared values and beliefs associated with the concept of play contributes to consistency in practice across different regions and cultural settings in Indonesia; it is also necessary.

Concerns have also been expressed about the importance of shared values and beliefs for the establishment of standard 
practice. The OECD and the Asian Development Bank (2015) state, "At the local level, many new early childhood institutions are authorised without any clear criteria or standards" (p. 27). This has led to inconsistent and incoherent policies. According to Elliot (2006), it is important to institute consistent and coherent policies across the national educational context in order to better establish learning and teaching outcomes.

\section{Contextual issues in fostering play- based programmes}

At the heart of this framework is the government's aim to provide play-based practice and its perception of investment in best practices for the child learning programme as the foundation for success and a better future. However, the implementation of the framework involves activities such as planning, implementation and assessment and the social context; altogether, these result in challenges. Regarding context, a range of studies indicate that some cultures place high value on the academic-learning approach and consider play-based programmes to be less important or a waste of time. The extent to which child education is valued impacts the implementation of play (Gaskins et al., 2007; Chudakoff, 2007). This is evidenced in another Asian countries, where children experience great academic pressure and their parents demand achievement in academic areas such as literacy, math, and the sciences (Choo et al., 2011; Trawick-Smith, 2010).

For example, regarding the implementation of a play-based programme in Singapore, Ng (2014) reports, "The teacher had not shifted her practice from the traditional worksheets teaching method" (p. 7). Her findings reveal that teachers focused on meeting parents' expectations concerning academic learning to help children achieve academic skills. Another example, according to Roopnarine et al. (2003), not all communities perceive play as being important for learning and development. Parents' attitudes towards child's play are important (Holmes, 2011; Vandermaas-Peeler, 2002; Roopnarine, 2010; Singer et al., 2009).

Similarly, in the Indonesian context, the parents of pre-school children had negative attitudes towards play in the pre-school. According to Mulia (2016), the parents and community had expectations that the preschool would provide a serious approach to learning. Her research findings show parents expected their children to receive extra homework so that they could control the children's leisure/play time at home. Moreover, the parents considered free play around the home after school to be a waste of time. Consequently, it could be said that the public's assumptions regarding what play looks like and social demands regarding approaches to child learning result in teachers and schools experiencing a range of challenges.

\section{Conclusion}

This essay argues that the Indonesian government is continuing to improve support for its play-based learning programme. However, parents who value the academic learning approach over play-based learning have challenged the programme. The evidence from the review suggests that not all social communities regard play-based learning programmes as the best practice for child education settings. Thus, it is necessary to improve awareness of the importance of play through a range of advanced parenting programmes.

\section{References}

Bertrand J. (2007). Preschool programs: Effective curriculum. Comments on Kagan and Kauerz and on Schweinhart. In R.E. Tremblay, R.G. Barr and R.deV. Peters (Eds.). 
Encyclopedia on early childhood development [online]. Montreal, Quebec: Centre of Excellence for early childhood development. Retrieved from http://www.excellenceearlychildhood.ca/documents/BertrandANGxp.pdf.

Choo, M. S., Xu, Y., and Haron, P. F. (2011). Subtypes of Nonsocial Play and Psychosocial Adjustment in Malaysian Preschool Children. Social Development. doi: 10.1111/j.14679507.2011.00630.x

Chudakoff, H.P. (2007). Children at Play: An American History. New York: New York University Press.

Departemen Pendidikan Nasional. (2009). Surat edaran nomor 1839/C.C2/TU/2009 tentang Penyelenggaraan Pendidikan Taman Kanak-Kanak dan Penerimaan Siswa Baru Sekolah Dasar.

Elliott, A. (2006). Early childhood education: pathways to quality and equity for all children. Australian Education Review No 50. Melbourne, Victoria: Australian Council for Educational Research Publishing, Paris. Retrieved from http://dx.doi. org/10.1787/9789264230750-en

Gaskins, S., Haight, W. and Lancy, D.F. (2007). The cultural construction of play. In A. Göncü and S. Gaskins (eds) Play and development: Evolutionary, Sociocultural and Functional Perspectives. Mahwah, NJ: Lawrence Erlbaum.

Morrissey, T. and Warner, M. (2007). Why early care and education deserves as much attention, or more, than prekindergarten alone. Applied Development Science, 11 (2), $57-70$.

Moss, P. (2007). Bringing politics into the nursery: Early childhood education as a democratic practice. Working Paper 43. The Hague, Netherlands: Bernard van Leer Foundation.

Mulia.(2016). The role of dramatic play in teaching English as a foreign language at preschool in Indonesian settings. Unpublished PhD thesis. Melbourne: Deakin University.

$\mathrm{Ng}$, J. (2014). The impact of children's learning during a curriculum reform in Singapore. International Research in Early Childhood Education, 5, 11-26. Retrieved from http:// www.monash.edu.au/education/research/outcomes/journals/irece/issues

OECD/Asian Development Bank (2015), Education in Indonesia: Rising to the Challenge, OECD.

Roopnarine, J. (2010). Cultural variations in beliefs about play, parent-child play, and children's play: Meaning for childhood development. In Pellegrini. The Oxford handbook of the development of play. New York: Oxford University Press.

Steglin, D. A. (2005). Making the case for play policy: Research-based reasons to support play-based environments. Young Children, 60(2), 76-86.

Trawick-Smith, J. (2010). Drawing back the lens on play: A Frame Analysis of Young Children's Play in Puerto Rico. Early Education and Development, 21(4), 536-567. 